\title{
Posturas éticas em Hortênsia de Hollanda
}

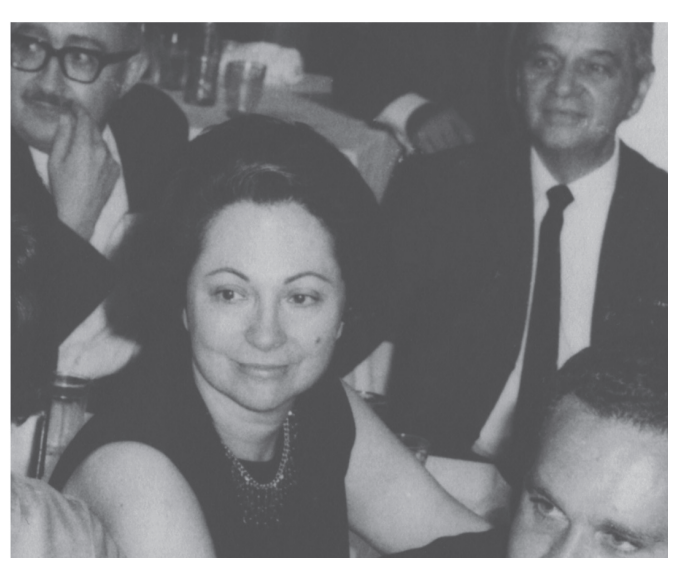

Profa. Hortênsia Hollanda durante o XVII Congresso Brasileiro de Higiene, Salvador, Bahia, Brasil, dezembro de 1968.
$\mathrm{H}$ ortênsia Hurpia de Hollanda ( $\star$ Corumbá/MS, 26/Mai/1917; † Votuporanga/SP, 05/Mai/2011) foi destas pessoas imprescindíveis, que mostrou em sua longa e preciosa vida uma interminável sequência de bons exemplos em Ética, Humanidade e Cidadania.

Ela nos deixou no mês de maio passado, cercada de respeito, de amigos e de muitas lembranças. Hortênsia é um ícone da moderna Educação Sanitária, tendo desempenhado inúmeros papéis como funcionária do Ministério da Saúde, da Organização Pan-Americana da Saúde e da Organização Mundial da Saúde, também prestando, incansavelmente, intermináveis consultorias a países, universidades, pessoas e instituições. Dentre as suas muitas qualidades pode-se destacar uma postura ética, intransigente e altamente pedagógica, razão porque a reverenciamos com saudade, neste pequeno texto, relembrando algumas passagens e condutas.

Hortênsia muito cedo se destacou na Saúde Pública brasileira, colaborando com Mário Pinotti, Manoel Ferreira, Rodrigues da Silva, Samuel Pessôa e outros pioneiros, em memoráveis lutas contra nossas principais doenças endêmicas. Era necessário chegar-se à comunidade e às pessoas, de um lado, como era também necessário incutir nas autoridades e cientistas o respeito e a compreensão ética concernente à sociedade. Hortência encarregou-se disto, em toda sua vida profissional.

Em seu livro/manual Saúde como Compreensão de Vida (1976; Convênio MS/MEC/PREMEN), o mote principal destaca o respeito pelo homem e seu papel de sujeito da vida. Tudo gira em torno da readmiração do dia a dia pelos alunos, seja no contexto da morada, seja na alimentação, seja na relação do homem com a natureza. $\mathrm{O}$ aluno é criança-sujeito, que tem reconhecida sua dignidade e apreende, aos poucos, seu papel protagonista na sociedade. O livro se constrói nesta admiração do entorno, na busca da saúde no sentido da apreensão das coisas ecológica e socialmente boas (fazer o bem), num contexto democrático e amplo da vida (universalidade). $\mathrm{O}$ aluno deve fotografar, auscultar, colher amostras de sua realidade. Ele aprende a entrar nas casas e valorizar a opinião das pessoas. A partir disto tudo, ele forma suas opiniões, às vezes auxiliado por um texto de apoio, também gerador de perguntas. O professor acompanha, estimula, acolhe. Tudo isso foi inovador e importante, máxime em se considerando o contexto da época, visceralmente repressora de liberdades e de articulações sociais. Por isso, entre outras razões, Hortênsia foi muitas vezes comparada a Paulo Freire, seu contemporâneo, o Educador para a Liberdade. Pena o Ministério da Educação e Cultura (MEC) não ter dado sequência ao projeto de implantação do manual. Certamente haverá razões fortes no contexto político da época.

Sob outro ângulo, pesquisadores e sanitaristas precisavam ir à comunidade, em projetos diversos que requeriam participação comu- 
nitária. Hortênsia reúne amigos e trabalha na difícil tarefa da análise do discurso. Enorme riqueza brota das falas humildes sobre malária, verminoses, doença de Chagas, peste, filariose e nutrição. Os educadores sanitários e os doutores começam a questionar sua própria soberba, que oprime e afasta as pessoas, através de expressões complicadas e ininteligíveis. Hortênsia ensina como chegar às localidades, apresentando-se sem afetação, respeitando a simplicidade, o desejo e o constrangimento do pobre (autonomia). Nunca invade. Para entrar ou fotografar, pede licença, permissão. Não manipula: valoriza as pessoas. Para todo o trabalho, ensina como explicar o que se vai fazer, de maneira compreensível e simples, jamais recorrendo a subterfúgios e inverdades. Mais do que um consentimento informado, às vezes tão burocrático, na prática de Hortênsia se impõem a confiança, a parceria e a boa cumplicidade entre sujeito e pesquisador.

No âmbito da relação com a comunidade, Hortênsia exige muito do pesquisador. Além da transparência das intenções, é fundamental não desencadear nenhum malefício com a investigação (primum non nocere). Nunca explorar a pobreza, através da arrogância ou de qualquer forma de poder, jamais "arrotar" superioridade. Certa feita, Hortênsia afrontou um ministro que solicitava que pobres professoras rurais abreviassem suas falas, para "não perder tempo". De máxima importância era sempre devolver a pesquisa à comunidade, de maneira explícita e formal. E quantos, até hoje, exploram e se vão sem dar satisfação, em nome da Ciência...

Muitos outros exemplos de postura ética poderiam ser trazidos neste texto por gente que teve o privilégio de sua convivência. Isto pode ser um projeto grande e muito oportuno, para quem puder dedicar-se a rever uma das mais importantes figuras da Saúde Pública contemporânea. Hortênsia, pelas sendas de sua prática, ensinou a ética através da própria vida.

\section{João Carlos Pinto Dias}

Centro de Pesquisas René Rachou, Fundação Oswaldo Cruz,

Belo Horizonte, Brasil.

jcpdias@cpqrr.fiocruz.br

Recebido em 18/Mai/2011

\section{Nota}

Consulte entrevista de Hortênsia de Hollanda concedida à Virgínia T. Schall e publicada sob a referência:

Schall VT. Alfabetizando o corpo: o pioneirismo de Hortênsia de Hollanda na educação em saúde. Cad. Saúde Pública

1999; 15 Suppl 2:149-159. 